\title{
Research ability in Chemistry and the Tuning Latin America specific competences: a comparative study at University of Cuyo (Argentina)*
}

\author{
Iris V. Dias, Armando Fernández Guillermet, \\ Carina E. Rubau, and María M. Tovar Toulouse
}

\begin{abstract}
Research ability can be thought of as a competence, which requires other abilities - both generic and specific - to be successfully developed. In this study, we determine the degree of importance that the 21 specific competences (SCs) established in the Tuning Latin America (Tuning-LA) Project, have in the acquisition of research ability in Chemistry, as a result of taking the degree program offered at the Facultad de Ciencias Exactas y Naturales, Universidad Nacional de Cuyo (FCENUNCUYO, Mendoza, Argentina). To this end, we adopted the SCs proposed as learning objectives in undergraduate studies in Chemistry, and consulted academics and students at FCEN-UNCUYO about (1) the importance of these competences in his/ her opinion for work in the profession; (2) the level of achievement of these competences, that they estimated was reached as a result of taking the FCEN-UNCUYO degree program in Chemistry; and, (3) the relevance of the Tuning-AL specific competences for the development of research ability in Chemistry. The results of the survey at FCEN-UNCUYO are compared with those obtained by consulting academics and students in the framework of the Tuning-LA Project. Detailed comparisons between the opinion of academics and students at FCEN- UNCUYO are also reported.
\end{abstract}

Keywords: Higher Education; Tuning Latin America; specific competences; research ability; research education; education in Basic Sciences; education in Chemistry.

\section{Introduction}

A key challenge in Higher Education is the improvement of the ability to perform research in undergraduate studies, since instructional sequences on research methodology do not necessarily guarantee that students develop the abilities needed to tackle successfully their degree thesis work. This problem

This work is part of the research project "Development of general education and research ability in an interdisciplinary context in undergraduate studies", which is carried out by the current authors at Facultad de Ciencias Exactas y Naturales (FCEN), Universidad Nacional de Cuyo (UNCUYO, Mendoza, Argentina). A research grant from SeCTyPUNCUYO is gratefully acknowledged. 
makes it desirable to incorporate research education as an explicit educational objective, i.e. to orient the educational practices towards the development of a multidimensional capacity, which will be referred to in the following as research ability. However, in order to move forward in designing, implementing and evaluating specific educational sequences to foster the development of this ability it is necessary, in the first place, to characterize research education and research ability.

The general objective of this study is to contribute to the characterization of research ability, in the framework of research education as an objective of the undergraduate studies in Chemistry at Facultad de Ciencias Exactas y Naturales, Universidad Nacional de Cuyo (FCEN-UNCUYO, Mendoza, Argentina). The specific objectives of the study are the following: (1) to compare the degree of importance and degree of achievement that academics and students of the FCEN - UNCUYO attribute to the 21 specific competences established by the Tuning Latin America (LA) Project for the Chemistry area; (2) to compare the results obtained at FCEN - UNCUYO with those obtained in the Tuning-LA Project; and, (3) to determine the degree of importance of the specific competences for the development of research ability in Chemistry.

\section{Theoretical framework: premises and previous results}

The current study is part of an interdisciplinary project carried out at FCEN-UNCUYO that seeks to identify the main competences that contribute to the development of research ability at the undergraduate level, and their potentiality to be developed in either classroom instruction and / or virtual environments. Previous studies by the current authors have dealt with the competence approach ${ }^{1}$ and the relation between research ability and the Tuning-LA generic competences. ${ }^{2},{ }^{3}$ Moving one step forward, the current

${ }^{1}$ Armando Fernández Guillermet and Carina Rubau, "El enfoque <por competencias $>$ en Educación Superior: conceptos clave, debates y aplicaciones en América Latina" (paper presented at XI Seminario Argentino Chileno and IV Seminario Cono Sur de Ciencias Sociales, Humanidades y Relaciones Internacionales, Universidad Nacional de Cuyo, Mendoza, Argentina, March 07-09, 2012).

2 Armando Fernández Guillermet and Carina Rubau, "La Capacidad de Investigación en un enfoque por competencias. Un estudio en el Instituto de Ciencias Básicas de la UNCUYO" (paper presented at III Jornadas de Enseñanza e Investigación Educativa en el campo de las Ciencias Exactas y Naturales, Facultad de Humanidades y Ciencias de la Educación, Universidad Nacional de La Plata, Buenos Aires, Argentina, September 26-28, 2012).

${ }^{3}$ Carina Rubau, Iris Dias, María M. Tovar Toulouse, and Armando Fernández Guillermet, "Importancia de las competencias genéricas Tuning-América Latina para el desarrollo de la 
work focuses on the research ability as an objective of research education of the undergraduate studies in Chemistry at FCEN-UNCUYO. The general premises adopted in this study are the following:

- In agreement with the traditional idea that "research cannot be learned in theoretical methodology courses, rather you learn to investigate side by side with a master, i.e., under someone's supervision", in the current paper research education is seen as the result of a dialogic interaction between an expert researcher and a novice, mediated by an object of investigation. In this dialogic interaction the expert acts as a role model who transmits the ways of doing and acting in the different areas of knowledge.

- Research education is seen as a multidimensional process that involves not only the acquisition of specific knowledge, methodologies and technical abilities, but also attitudes, dispositions and values. To characterize this set of knowledge, methodologies, attitudes, dispositions and values, the present study adopts the competence approach. ${ }^{4}{ }^{5} \mathrm{~A}$ "competence" is viewed here as the ability to mobilize, in a contextually determined problem situation the set of elements that allows us to act pertinently, efficiently, and adjusted to norms, principles and values. ${ }^{6}$

- Research education is conceived as a process through which a student develops an articulated set of competences that contribute - to a greater or lesser extent - to the development of a key ability, the integrator of these competences, research ability. ${ }^{7}$ It is accepted that some of the competences that contribute to the development of research ability are general to any degree, and some are specific or subject-area related. In a tentative manner, and not leaving aside other

formación para la investigación. Estudio comparativo en el Instituto de Ciencias Básicas de la Universidad Nacional de Cuyo (Argentina), "Enseñanza de las Ciencias, Número Extraordinario (2013): 3114-3119.

${ }^{4}$ Robert Wagenaar, "Competences and learning outcomes: a panacea for understanding the (new) role of Higher Education?" Tuning Journal for Higher Education 1, no. 2 (2014): 279-302.

5 Pablo Beneitone and Edurne Bartolomé, "Global generic competences with local ownership: a comparative study from the perspective of graduates in four world regions," Tuning Journal for Higher Education 1, no. 2 (2014): 303-334.

${ }^{6}$ Fernández Guillermet and Rubau, "El enfoque <por competencias> en Educación Superior."

${ }^{7}$ Fernández Guillermet and Rubau, "La Capacidad de Investigación en un enfoque por competencias." 
alternatives to explore in the future, in the current work it is accepted that the competences independent of the discipline that contribute to the development of research ability ${ }^{8}$ are those established as generic competences (GCs) by the Tuning-LA Project. ${ }^{9}$ In the current work it is also accepted tentatively that the competences that are specific to each area of knowledge are those established as specific competences (SCs) for various disciplines by the Tuning-LA Project.

- It is accepted that the Ability for the planning, design, and running of research projects, which is one of the SCs for undergraduate studies in Chemistry established in the Tuning-LA Project, expresses the research ability in this discipline..$^{10}$ The relation between this competence and the other Tuning-LA SCs for Chemistry will be studied using the methodology which is described in the following section.

\section{Methodology}

The Tuning - LA Project consulted academics, graduates, employees and students from a large number of countries. ${ }^{11}$ Since FCEN - UNCUYO did not participate of that survey, we decided to carry out a similar questionnaire at this institution with three main objectives: (1) to learn the opinion of academics and students about the degree of importance and achievement of the SCs for Chemistry; (2) to compare these results with those obtained at the Tuning-LA Project, and (3) to learn the opinion of academics and students at the FCEN-UNCUYO about the relative importance of the SCs for the development of research ability. To this end, a structured survey was administered to students and academics in the area of Chemistry at FCEN - UNCUYO, which consisted of three parts:

- Personal information. Academics were asked about their labour situation and students about their secondary school studies and personal interests prior to their immersion in higher education.

${ }^{8}$ Rubau et al., "Importancia de las competencias genéricas."

9 Pablo Beneitone, César Esquetini, Julia González, Maida Marty Maletá, Gabriela Siufi, and Robert Wagenaar, eds., Reflections on and outlook for Higher Education in Latin America (Bilbao: University of Deusto, 2007).

10 Beneitone et al., Reflections on and outlook for...

11 Argentina, Bolivia, Brasil, Colombia, Costa Rica, Cuba, Chile, Ecuador, El Salvador, Guatemala, Honduras, México, Nicaragua, Panamá, Paraguay, Perú, Uruguay y Venezuela. 
- Degree of importance and achievement of the 21 SCs established by the Tuning-LA Project for undergraduate studies in Chemistry. The respondents were asked to quantify the importance and achievement of each of the SCs using the four grade scale used by Tuning-LA, from 1 $=$ none to $4=$ strong.

- Degree of importance that the achievement of the SCs would have for the development of the Ability for the planning, design, and running of research projects, which is considered in the remainder of the current work as a formulation of the research ability in Chemistry.

Twenty three out of twenty eight academics of the Chemistry area of FCEN-UNCUYO answered the survey, out of which $4.3 \%$ are full professors, $8.7 \%$ are associate professors, $39.1 \%$ are assistant professors, $21.7 \%$ are teaching assistants in charge of the practice ("JTP"), $8.7 \%$ are teaching assistants, and $17.4 \%$ are ad honorem teaching assistants. More than half of the academics $(69.5 \%)$ have a post-graduate degree (specialization, master or doctorate), $26.1 \%$ are undertaking graduate studies, and $4.3 \%$ have only an undergraduate degree. As regards the age of the respondents, $30.5 \%$ are 35 years old or less, $47.8 \%$ are between 35 and 49 years old, and $21.7 \%$ are 50 years old or more. Fifteen advanced students answered the survey. Most of the respondents $(93.3 \%)$ are studying to get a "Licenciado" degree in Chemistry and $6.7 \%$ are studying to become Teachers of Chemistry. As regards the age of the students, $26.7 \%$ are 22 years old or less, $60 \%$ are between 22 and 27 years old, and $13.3 \%$ are 27 years old or more.

\section{Results}

The average scores for degree of importance and degree of achievement assigned by the respondents to each of the SCs are presented and discussed in the following. In Table 1 the 21 SCs established for the area of Chemistry by the Tuning-LA project are presented in decreasing order of importance assigned by the academics at FCEN-UNCUYO. The degree of importance that each of the other SCs would have for the successful development of the Ability for the planning, design, and running of research projects - which is listed in Table 1 as SC18 - is also shown. SC18 will be referred to in the following as research ability in Chemistry. 


\section{Table 1}

Average values, assigned by students and academics at FCEN - UNCUYO, for the degree of importance of the 21 Specific competences (SCs) established

by the Tuning-LA project, and degree of importance for the development of research ability (SC18) that each of the other 20 SC represents, according to students and academics at FCEN - UNCUYO

\begin{tabular}{|c|c|c|c|c|c|}
\hline & \multirow[t]{2}{*}{$\begin{array}{l}\text { SC in decreasing order of } \\
\text { importance assigned by } \\
\text { academics at } \\
\text { CEN - UNCUYO }\end{array}$} & \multicolumn{2}{|c|}{$\begin{array}{l}\text { Degree of } \\
\text { importance }\end{array}$} & \multicolumn{2}{|c|}{$\begin{array}{l}\text { Degree of } \\
\text { importance for } \\
\text { the succesful } \\
\text { development of } \\
\text { research ability }\end{array}$} \\
\hline & & Academics & Students & Academics & Students \\
\hline SC1 & $\begin{array}{l}\text { Understanding the } \\
\text { principles, concepts, and } \\
\text { basic theories of Chemistry. }\end{array}$ & 4.000 & 3.933 & 3.869 & 3.867 \\
\hline SC2 & $\begin{array}{l}\text { Mastery of the the } \\
\text { chemical terminology, } \\
\text { nomenclature, conventions, } \\
\text { and units. }\end{array}$ & 3.826 & 3.800 & 3.739 & 3.6 \\
\hline SC 3 & $\begin{array}{l}\text { Knowledge and application } \\
\text { of good laboratory practice } \\
\text { and quality assurance. }\end{array}$ & 3.826 & 3.400 & 3.696 & 3.7 \\
\hline SC 4 & $\begin{array}{l}\text { Ability to understand } \\
\text { and apply knowledge } \\
\text { of Chemistry to solve } \\
\text { quantitative and } \\
\text { qualitative problems. }\end{array}$ & 3.783 & 3.733 & 3.609 & 3.8 \\
\hline SC 5 & $\begin{array}{l}\text { Ability to interpret and } \\
\text { evaluate data derived } \\
\text { from observations and } \\
\text { measurements, relating it } \\
\text { to theory. }\end{array}$ & 3.739 & 3.600 & 3.783 & 3.8 \\
\hline SC 6 & $\begin{array}{l}\text { Ability to act with curiosity, } \\
\text { initiative, and endeavor. }\end{array}$ & 3.696 & 3.400 & 3.652 & 3.533 \\
\hline SC 7 & $\begin{array}{l}\text { Ability to recognize and } \\
\text { analyse problems, and to } \\
\text { plan strategies for their } \\
\text { solution. }\end{array}$ & 3.609 & 3.467 & 3.739 & 3.8 \\
\hline SC 8 & $\begin{array}{l}\text { Ability to use, apply } \\
\text { and develop analytical } \\
\text { techniques. }\end{array}$ & 3.609 & 3.533 & 3.391 & 3.8 \\
\hline
\end{tabular}




\section{Table 1}

Average values, assigned by students and academics at FCEN - UNCUYO, for the degree of importance of the 21 Specific competences (SCs) established by the Tuning-LA project, and degree of importance for the development of research ability (SC18) that each of the other 20 SC represents, according to students and academics at FCEN - UNCUYO (continued)

\begin{tabular}{|c|c|c|c|c|c|}
\hline & \multirow[t]{2}{*}{$\begin{array}{l}\text { SC in decreasing order of } \\
\text { importance assigned by } \\
\text { academics at } \\
\text { CEN - UNCUYO }\end{array}$} & \multicolumn{2}{|c|}{$\begin{array}{l}\text { Degree of } \\
\text { importance }\end{array}$} & \multicolumn{2}{|c|}{$\begin{array}{l}\text { Degree of } \\
\text { importance for } \\
\text { the succesful } \\
\text { development of } \\
\text { research ability }\end{array}$} \\
\hline & & Academics & Students & Academics & Students \\
\hline SC 9 & $\begin{array}{l}\text { Ability to apply knowledge } \\
\text { of Chemistry in sustainable } \\
\text { development. }\end{array}$ & 3.609 & 3.267 & 3.348 & 3.2 \\
\hline SC 10 & $\begin{array}{l}\text { Ability to monitor events } \\
\text { and changes through } \\
\text { measurement and } \\
\text { observation of chemical } \\
\text { properties, and to compile } \\
\text { and document them in } \\
\text { a systematic and reliable } \\
\text { fashion. }\end{array}$ & 3.524 & 3.467 & 3.522 & 3.533 \\
\hline SC 11 & $\begin{array}{l}\text { Knowledge of the English } \\
\text { language to read, write, } \\
\text { and present documents as } \\
\text { well as to communicate } \\
\text { with other specialists. }\end{array}$ & 3.478 & 3.533 & 3.609 & 3.4 \\
\hline SC 12 & $\begin{array}{l}\text { Ability for the presentation } \\
\text { of scientific information to } \\
\text { different audiences in both } \\
\text { oral and written form. }\end{array}$ & 3.478 & 3.467 & 3.652 & 3.4 \\
\hline SC 13 & $\begin{array}{l}\text { Ability in the use } \\
\text { of new information } \\
\text { and communications } \\
\text { technology applied to } \\
\text { Chemistry. }\end{array}$ & 3.454 & 3.467 & 3.522 & 3.533 \\
\hline SC 14 & $\begin{array}{l}\text { Knowledge and deep } \\
\text { understanding of a specific } \\
\text { area of Chemistry. }\end{array}$ & 3.435 & 3.600 & 3.696 & 3.467 \\
\hline SC 15 & $\begin{array}{l}\text { Ability to participate in } \\
\text { work teams. }\end{array}$ & 3.435 & 3.333 & 3.348 & 3.333 \\
\hline
\end{tabular}




\section{Table 1}

Average values, assigned by students and academics at FCEN - UNCUYO, for the degree of importance of the 21 Specific competences (SCs) established

by the Tuning-LA project, and degree of importance for the development of research ability (SC18) that each of the other 20 SC represents, according to students and academics at FCEN - UNCUYO (continued)

\begin{tabular}{|c|c|c|c|c|c|}
\hline & \multirow[t]{2}{*}{$\begin{array}{l}\text { SC in decreasing order of } \\
\text { importance assigned by } \\
\text { academics at } \\
\text { CEN - UNCUYO }\end{array}$} & \multicolumn{2}{|c|}{$\begin{array}{l}\text { Degree of } \\
\text { importance }\end{array}$} & \multicolumn{2}{|c|}{$\begin{array}{l}\text { Degree of } \\
\text { importance for } \\
\text { the succesful } \\
\text { development of } \\
\text { research ability }\end{array}$} \\
\hline & & Academics & Students & Academics & Students \\
\hline SC 16 & $\begin{array}{l}\text { Knowledge of the } \\
\text { frontiers of research and } \\
\text { development in Chemistry. }\end{array}$ & 3.409 & 3.467 & 3.174 & 3.267 \\
\hline SC 17 & $\begin{array}{l}\text { Knowledge of other } \\
\text { scientific disciplines } \\
\text { necessary for the } \\
\text { understanding of } \\
\text { Chemistry. }\end{array}$ & 3.391 & 3.333 & 3.217 & 3.333 \\
\hline SC 18 & $\begin{array}{l}\text { Ability for the planning, } \\
\text { design, and running of } \\
\text { research projects. }\end{array}$ & 3.391 & 3.467 & - & - \\
\hline SC 19 & $\begin{array}{l}\text { Knowledge of the main } \\
\text { synthetic routes in } \\
\text { Chemistry. }\end{array}$ & 3.318 & 3.267 & 3.000 & 3.267 \\
\hline SC 20 & $\begin{array}{l}\text { Knowledge, application, } \\
\text { and assessment on the } \\
\text { legal frame in the field of } \\
\text { Chemistry. }\end{array}$ & 3.174 & 3.200 & 3.087 & 2.933 \\
\hline SC 21 & $\begin{array}{l}\text { Understanding of } \\
\text { epistemology of Science. }\end{array}$ & 2.826 & 3.000 & 2.956 & 2.733 \\
\hline
\end{tabular}

The results in Table 1 indicate that academics at the FCEN - UNCUYO assign a higher degree of importance to $7 \mathrm{SCs}$ when related to the development of research ability than when related to specific competences per se. Similarly, students assign to $8 \mathrm{SCs}$ a higher degree of importance when related to research ability. Both groups assign:

- A higher degree of importance for the development of research ability to the competences SC5 (Ability to interpret and evaluate 
data derived from observations and measurements, relating it to theory), SC7 (Ability to recognize and analyse problems, and to plan strategies for their solution), and SC13 (Ability in the use of new information and communications technology applied to Chemistry).

- A lower degree of importance for the development of research ability to the competences SC1 (Understanding the principles, concepts, and basic theories of Chemistry), SC2 (Mastery of the chemical terminology, nomenclature, conventions, and units), SC9 (Ability to apply knowledge of Chemistry in sustainable development), SC16 (Knowledge of the frontiers of research and development in Chemistry) and SC20 (Knowledge, application, and assessment on the legal frame in the field of Chemistry).

The students at FCEN - UNCUYO consider that SC15 (Ability to participate in work teams), SC17 (Knowledge of other scientific disciplines necessary for the understanding of Chemistry) and SC19 (Knowledge of the main synthetic routes in Chemistry) are equally important either for the development of research ability or as SC per se.

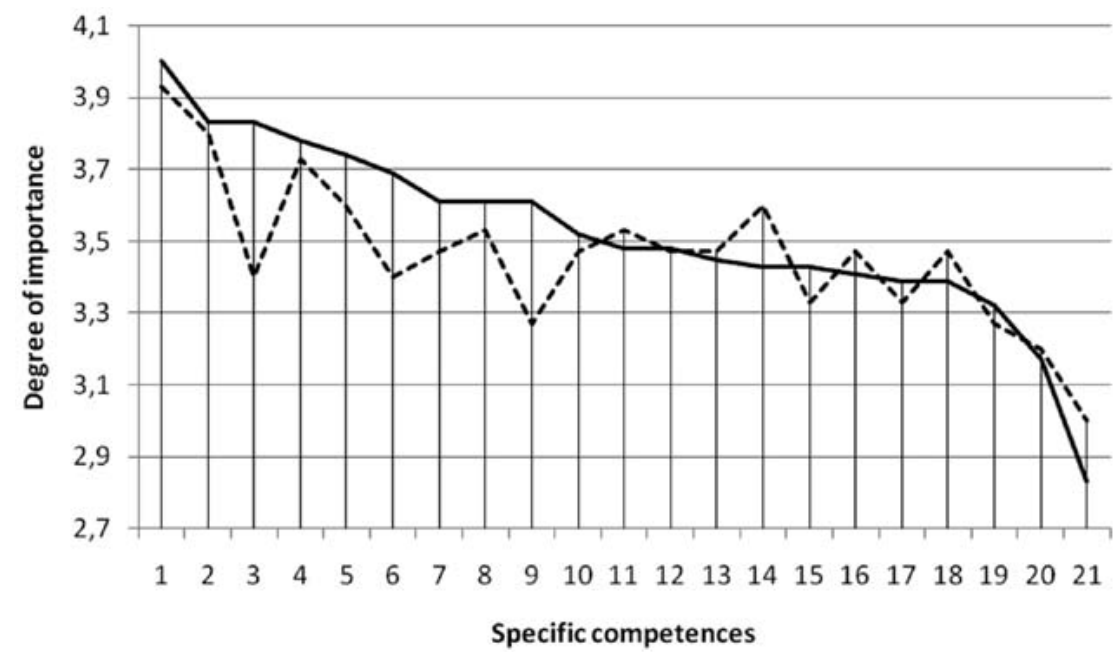

- Academics ------Students

Figure 1

Average values of degree of importance assigned to the 21 SCs by academics and students at FCEN - UNCUYO 
In Figure 1, the average values of degree of importance assigned by academics to the $21 \mathrm{SCs}$ are compared with those assigned by students at FCEN - UNCUYO. Academics have assigned a:

- Higher degree of importance to the competences SC1 (Understanding the principles, concepts, and basic theories of Chemistry), SC3 (Knowledge and application of good laboratory practice and quality assurance), SC4 (Ability to understand and apply knowledge of Chemistry to solve quantitative and qualitative problems), SC5 (Ability to interpret and evaluate data derived from observations and measurements, relating it to theory), SC6 (Ability to act with curiosity, initiative, and endeavor), SC7 (Ability to recognize and analyse problems, and to plan strategies for their solution), SC8 (Ability to use, apply, and develop analytical techniques), SC9 (Ability to apply knowledge of Chemistry in sustainable development), SC10 (Ability to monitor events and changes through measurement and observation of chemical properties, and to compile and document them in a systematic and reliable fashion), $\mathrm{SC} 15$ (Ability to participate in work teams), SC17 (Knowledge of other scientific disciplines necessary for

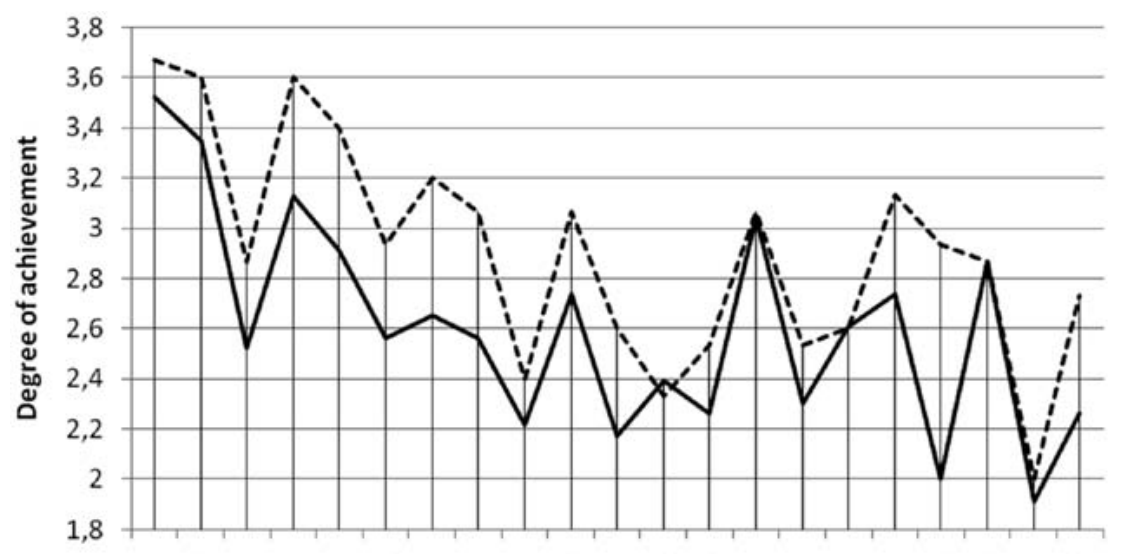

$\begin{array}{lllllllllllllllllllll}1 & 2 & 3 & 4 & 5 & 6 & 7 & 8 & 9 & 10 & 11 & 12 & 13 & 14 & 15 & 16 & 17 & 18 & 19 & 20 & 21\end{array}$

Specific competences

- Academics -----S Students

Figure 2

Average values of degree of achievement assigned to the 21 SCs by academics and students at FCEN - UNCUYO 
the understanding of Chemistry) and SC19 (Knowledge of the main synthetic routes in Chemistry).

- Lower degree of importance to the competences SC14 (Knowledge and deep understanding of a specific area of Chemistry), SC16 (Knowledge of the frontiers of research and development in Chemistry), SC18 (Ability for the planning, design, and running of research projects) and SC21 (Understanding of epistemology of Science).

In Figure 2, the average values of degree of achievement assigned by academics to the $21 \mathrm{SCs}$ are compared with those assigned by students at FCEN - UNCUYO. In general, students have assigned a higher degree of achievement to most of the SCs. Both groups assign similar values to the competences SC12 (Ability for the presentation of scientific information to different audiences in both oral and written form), SC14 (Knowledge and deep understanding of a specific area of Chemistry), SC16 (Knowledge of the frontiers of research and development in Chemistry) and SC19 (Knowledge of the main synthetic routes in Chemistry).

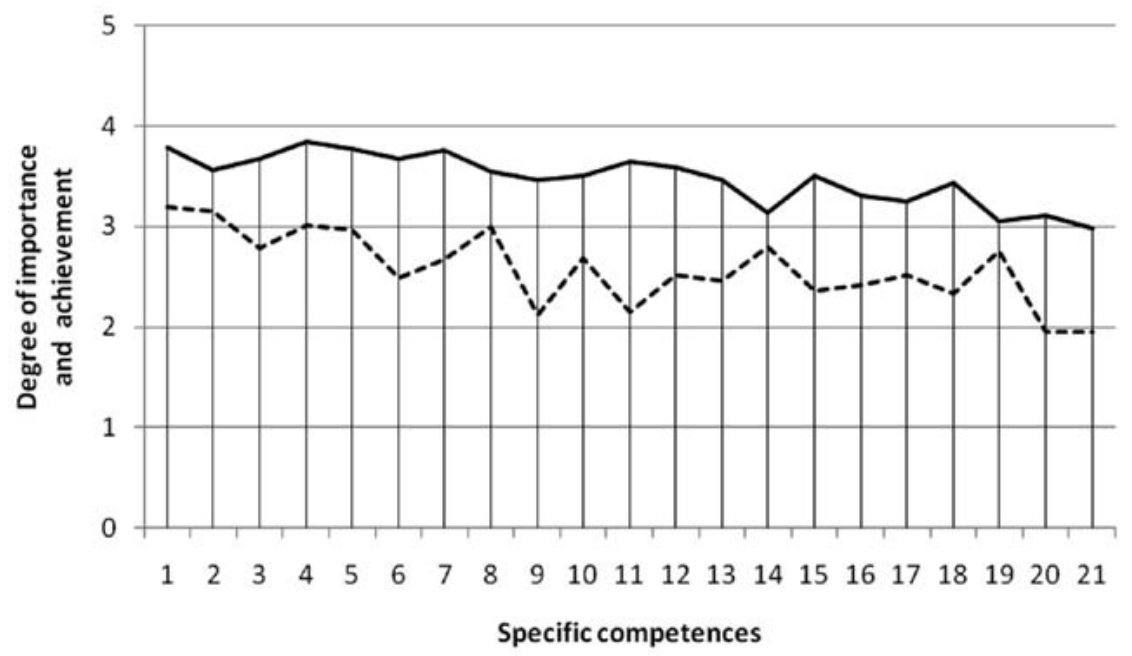

- Importance -----Achievement

Figure 3

Average values of degree of importance and achievement assigned to the 21 SCs by academics surveyed in the Tuning-LA Project 


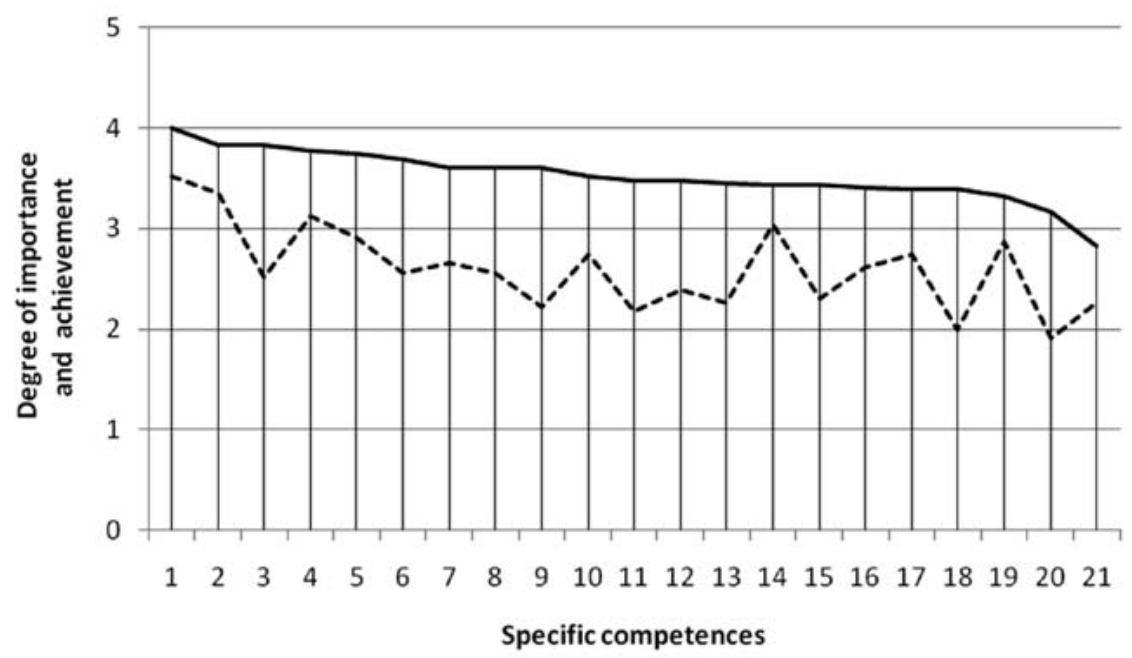

- Importance ----- Achievement

Figure 4

Average values of degree of importance and achievement assigned to the 21 SCs by academics surveyed at FCEN - UNCUYO

In Figures 3 to 6, the results of the current survey are compared to those obtained by the Tuning-LA Project. Figures 3 and 4 show that academics in both surveys agree that the degree of importance of all SCs is higher than the corresponding degree of achievement. However, the average scores assigned by academics in the Tuning-LA Project show a wider variability. In addition, the academics in both surveys agree that:

- The SCs with similar values between degree of importance and achievement are: SC14 (Knowledge and deep understanding of a specific area of Chemistry) and SC19 (Knowledge of the main synthetic routes in Chemistry).

- The SCs with different values between degree of importance and degree of achievement are: SC9 (Ability to apply knowledge of Chemistry in sustainable development), SC11 (Knowledge of the English language to read, write, and present documents as well as to communicate with other specialists) and SC20 (Knowledge, application, and assessment on the legal frame in the field of Chemistry). 
Figures 5 and 6 show that the students consulted in the Tuning-LA Project and those at the FCEN - UNCUYO share similar appreciation in that:

- Each of the SCs have a higher degree of importance than degree of achievement.

- The competences that present a closer degree of importance and degree of achievement are: SC2 (Mastery of the chemical terminology, nomenclature, conventions, and units) and SC19 (Knowledge of the main synthetic routes in Chemistry).

- The competence that presents the lowest degree of achievement is SC20 (Knowledge, application, and assessment on the legal frame in the field of Chemistry).

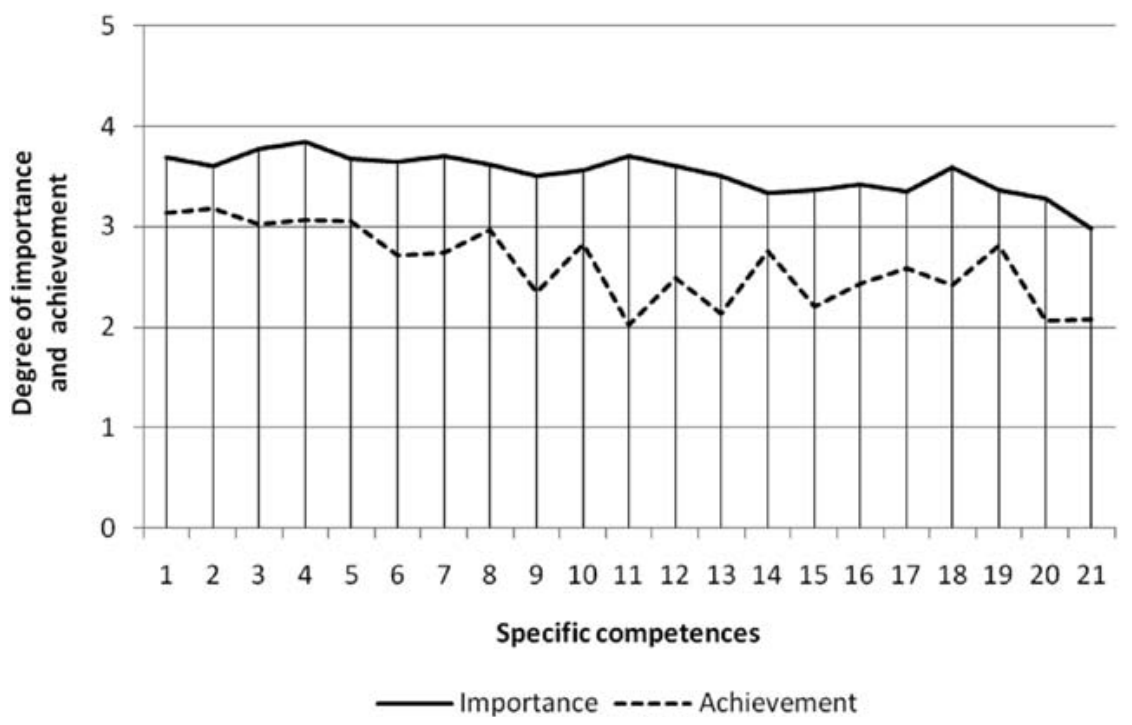

Figure 5

Average values of degree of importance and achievement assigned to the 21 SCs by students surveyed in the Tuning-LA Project 


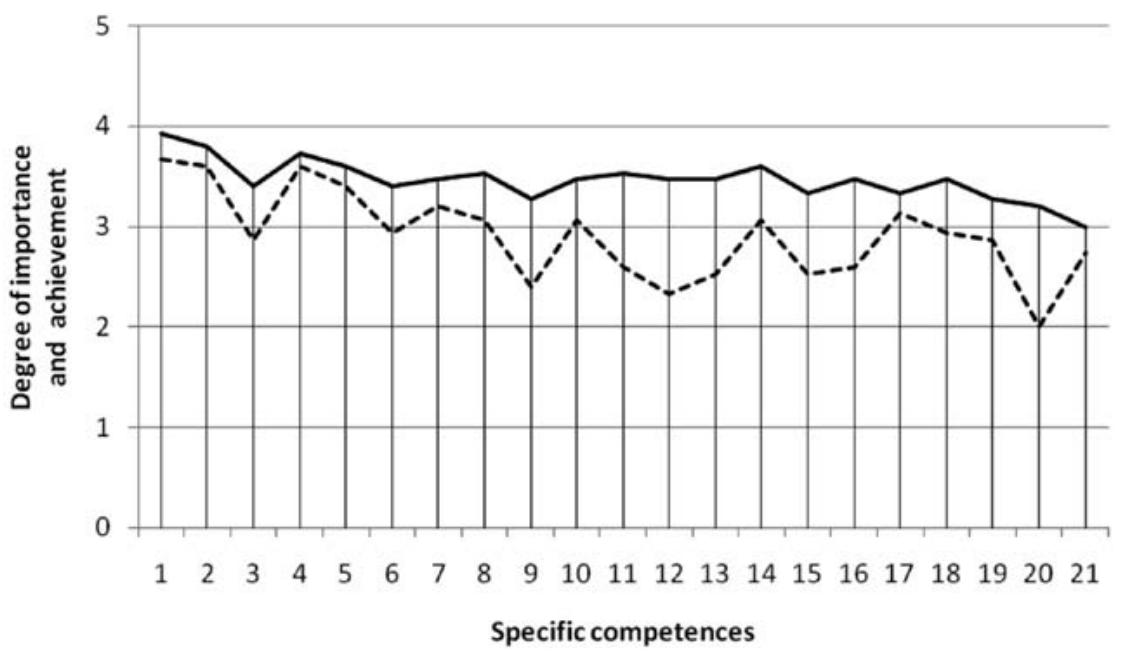

- Importance ------Achievement

Figure 6

Average values of degree of importance and achievement assigned to the 21 SCs by students at FCEN - UNCUYO

\section{Summary and concluding remarks}

The general aim of the current study is to contribute to the characterization of research education in undergraduate studies in Chemistry at Facultad de Ciencias Exactas y Naturales, Universidad Nacional de Cuyo (FCENUNCUYO, Mendoza, Argentina) adopting a competence approach. The work focuses on research ability, understanding it as a multidimensional competence, which requires the development of other competences, both generic and specific. In the current study, the Ability for the planning, design, and running of research projects, which is one of the 21 specific competences in Chemistry established by the Tuning-LA Project, is considered as a specific formulation of research ability. Thereby, the relationship of this competence with the other 20 SCs proposed for this subject area was studied. To this end two surveys were administered to students and academics at FCEN-UNCUYO. The first survey, similar to the one carried out in the Tuning-LA Project, had two objectives: (1) learn the opinion of academics 
and students with respect to the importance and achievement of the 21 SCs; and (2) determine coincidences and discrepancies with the tendencies established by a great number of universities, by comparing the results obtained in this study to those of the Tuning-LA Project. The second survey enquired about the importance of each of the remaining $20 \mathrm{SCs}$ for the development of the Ability for the planning, design, and running of research projects. The most relevant findings of the study are the following.

- In both the Tuning-LA Project and the current study it was found that: (1) academics agree in assigning a similar degree of importance and degree of achievement to the competences Knowledge and deep understanding of a specific area of Chemistry and Knowledge of the main synthetic routes in Chemistry; and, (2) students consider that the competences that show a major agreement between degree of importance and degree of achievement are Mastery of the chemical terminology, nomenclature, conventions, and units and Knowledge of the main synthetic routes in Chemistry. We note that the SCs involved in (1) and (2) are related to the acquisition of theoretical knowledge, which is the kind of content traditionally considered as the main educational objective of Higher Education. These results suggest that both groups consulted consider that the competences which are given priority among the educational objectives in traditional teaching are better achieved.

- The current study, which assesses the relevance of the SCs established in the Tuning-LA Project into the development of research ability, also has relevance for that project as it shows how the other SCs relate to the development of SC18 (Ability for the planning, design, and running of research projects). It is the opinion of academics and students at the FCEN - UNCUYO that a higher degree of importance for the development of research ability than as SC per se correspond to the Ability to interpret and evaluate data derived from observations and measurements, relating it to theory, Ability to recognize and analyse problems, and to plan strategies for their solution and Ability in the use of new information and communications technology applied to Chemistry. These three SCs are closely related to the cognitive and methodological dimensions of Higher Education.

- Comparison of the results of the Tuning-LA survey to those of the FCEN-UNCUYO survey highlights the fact that academics assign a low degree of achievement to the Knowledge of the English language to read, write, and present documents as well as to communicate with other specialists. This competence, little achieved in undergraduate 
studies, was established in a previous survey to academics and researchers carried out by the current group in Mendoza (Argentina) as one of the competences that favor research ability. ${ }^{12}$ Moreover, academics and students at FCEN - UNCUYO assign a relatively low degree of achievement to the Ability for the presentation of scientific information to different audiences in both oral and written form. The achievement of these two SCs, related to research ability, should be taken into consideration when posing educational objectives and strategies so as to strengthen research education.

\section{Bibliography}

Beneitone, Pablo, and Edurne Bartolomé. "Global generic competences with local ownership: a comparative study from the perspective of graduates in four world regions." Tuning Journal for Higher Education 1, no. 2 (2014): 303-334.

Beneitone, Pablo, César Esquetini, Julia González, Maida Marty Maletá, Gabriela Siufi, and Robert Wagenaar, eds. Reflections on and outlook for Higher Education in Latin America. Bilbao: University of Deusto, 2007.

Fernández Guillermet, Armando, and Carina Rubau. "El enfoque <por competencias $>$ en Educación Superior: conceptos clave, debates y aplicaciones en América Latina." Paper presented at XI Seminario Argentino Chileno y IV Seminario Cono Sur de Ciencias Sociales, Humanidades y Relaciones Internacionales, Universidad Nacional de Cuyo, Mendoza, Argentina, March 07-09, 2012.

. "La Capacidad de Investigación en un enfoque por competencias. Un estudio en el Instituto de Ciencias Básicas de la UNCUYO.” Paper presented at III Jornadas de Enseñanza e Investigación Educativa en el campo de las Ciencias Exactas y Naturales, Facultad de Humanidades y Ciencias de la Educación, Universidad Nacional de La Plata, Buenos Aires, Argentina, September 26-28, 2012.

Rubau, Carina, Iris V. Dias, María Mercedes Tovar Toulouse, and Armando Fernández Guillermet. «Importancia de las competencias genéricas TuningAmérica Latina para el desarrollo de la formación para la investigación. Estudio comparativo en el Instituto de Ciencias Básicas de la Universidad Nacional de Cuyo (Argentina).» Enseñanza de las Ciencias, Número Extraordinario (2013): 3114-3119.

Tovar Toulouse, María M., Carina E. Rubau, and Iris V. Días. «Haciéndonos amigos de la ciencia. Inglés, la lengua franca de la comunicación científica en la

${ }_{12}$ María M. Tovar Toulouse, Carina E. Rubau, and Iris V. Dias, "Haciéndonos amigos de la ciencia. Inglés, la lengua franca de la comunicación científica en la Universidad Nacional de Cuyo" (paper presented at Congreso Latinoamericano de Ingeniería y Ciencias Aplicadas - CLICAP 2012, Facultad de Ciencias Aplicadas a la Industria, Universidad Nacional de Cuyo, San Rafael, Mendoza, Argentina, March 28-30, 2012). 
Universidad Nacional de Cuyo.» Paper presented at Congreso Latinoamericano de Ingeniería y Ciencias Aplicadas, CLICAP 2012, Facultad de Ciencias Aplicadas a la Industria, Universidad Nacional de Cuyo, San Rafael, Mendoza, Argentina, March 28-30, 2012.

Wagenaar,Robert. "Competences and learning outcomes: a panacea for understanding the (new) role of Higher Education?" Tuning Journal for Higher Education 1, no. 2 (2014): 279-302. 